\title{
Koulutettu naiskansalainen suomalaisessa hyvinvointivaltiossa - johdatus teemaan
}

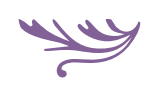

Koulutuksen, työelämän ja hyvinvointiyhteiskunnan murrokset ovat muokanneet naiskansalaisuutta läpi vuosikymmenten. Sari Sairaanhoitajan kuvitteellinen tarina elämänvaiheineen nivoo yhteen tyttö-, nais- ja hoivakansalaisuuden rakentumisen koulutuksessa, omaishoivassa ja työelämän reunaehdoissa.

TÄMÄN TEEMANUMERON ARTIKKELIT valottavat naisten elämää suomalaisen hyvinvointivaltion kasvun ja supistusten vuosikymmeninä 1970-luvulta 2010-luvulle. Artikkeleissa kulkee mukana Sari Sairaanhoitaja, kuvitteellinen hahmo, jonka elämänkulkuun kietoutuen kuvataan kansalaisuuden ulottuvuuksia - tyttökansalaisuutta, naiskansalaisuutta ja hoivakansalaisuutta. Kehystarina kerrotaan tämän johdannon päätteeksi.

Sarin tarina sitoo yhteiskunnalliset tapahtumat yksilölliseen perspektiiviin, joka fiktiivisyydessäänkin on uskottava juuri tästä syystä. Se ilmentää suomalaisen yhteiskunnan muutoksia sellaisina kuin ne ovat samoja vuosikymmeniä, saman ikäisinä eläneiden suomalaisten "kollektiivisessa muistissa". Kietoutuessaan yhteiskunnalliseen muutokseen, tulee yksityisistäkin tarinoista poliittisia (Guaraldo 2001).

Kansalaisuus hallinnollisesti ymmärrettynä merkitsee valtion jäsenyyttä ja yksityisen henkilön ja kansallisvaltion välistä suhdetta. Tämä on kansalaisuuden juridispoliittinen osa, jossa korostuvat poliittisesti ja juridisesti määritellyt oikeudet ja velvollisuudet. Yhtä tärkeitä ovat kansalaisuuden kulttuuriset ja sosiaaliset ulottuvuudet, jotka perustuvat arkielämässä tapahtuvaan poliittiseen ja käytännölliseen rajanve- 
toon toimijuuksista, identiteeteistä ja asemista. (Pyykkönen 2007.)

Kulttuurinen kansalaisuus on kollektiivinen ja emotionaalinen kokemus, jossa kansalainen muodostaa henkilökohtaisen suhteen kansalliseen- tai valtakulttuuriin. Kansalaisuuden sosiaalinen ulottuvuus tarkoittaa sitä, että yksilön sosiaalinen asema vaikuttaa hänen mahdollisuuksiinsa toimia kansalaisena. Esteitä kansalaisuuden toteuttamiselle tuottavat identiteetteihin, statukseen ja rooleihin liittyvät tekijät, kuten vammaisuus, sukupuoli, varallisuus ja etnisyys. (Harinen 2000.)

Hyvinvointivaltion yhtenä tavoitteena on madaltaa näitä kansalaisuuden esteitä luomalla eri ihmisryhmille mahdollisimman tasa-arvoiset elinolosuhteet. Hyvinvointivaltion sosiaalipolitiikassa, laeissa ja sosiaalipoliittisissa asiakirjoissa, puhutellaan ja määritellään kansalaisia ja kansalaisuutta. Viime vuosikymmeninä kansalaisuuden määrittelyihin on yhä enemmän sisällytetty aktivointia, vastuuttamista ja valtaistamista. (Julkunen 2006.)

Suomalaisen ja pohjoismaisen, naisystävälliseksikin kutsutun, hyvinvointivaltion tarkoitus on suojata kansalaisia köyhyydeltä ja muilta sosiaalisilta ongelmilta, ja tehdä se naisten eritystarpeet huomioiden. Naisystävällisyys tarkoittaa sitä, että myös naisille luodaan mahdollisuudet itsenäiseen, omaehtoiseen elämään ja täysimääräiseen julkiseen elämään osallistumiseen. Naisystävällisen hyvinvointivaltion osoituksina pidetään naisten korkeaa ansiotyöhön osallistumista, parlamentaarisen edustuksen tasa-arvoisuutta, työssäkäyntiä helpottavia julkisia palveluita ja sosiaaliturvan yksilöllisyyttä. (Julkunen 1992; Anttonen 1997.)

Teemanumeron artikkeleissa tarkastellaan koulutuksen ja sivistyksen nivoutumista hyvinvointivaltioon ja sukupuoleen. Historiallisesti hoiva- ja hoitotyö on ollut hyvinvointivaltion naiskansalaiselle tärkeä kanava päästä palkansaajaksi mieskansalaisen rinnalle. Vuonna 2014 suomalaiset työssä olevat naiset toimivat yleisimmin hoivapalvelun ja terveydenhuollon aloilla. Toiseksi yleisin ammatti oli myyjä ja kolmanneksi yleisimmin naiset toimivat opetustehtävissä. Neljänneksi yleisin ammatti oli terveydenhuollon asiantuntija, kuten sairaanhoitaja. (Tilastokeskus 2016.)

Artikkeleiden kirjoittajat ovat kiinnostuneita siitä, miten tyttökansalaisuutta, naiskansalaisuutta ja hoivakansalaisuutta rakennetaan erilaisissa kehyksissä: peruskoulussa, ammatillisessa koulutuksessa, omaishoivassa, työelämän reunaehdoissa, kansalaisten näkemyksissä sekä yhteiskunta-, koulutus- ja sosiaalipoliittisissa ideaaleissa.

Yksilöitä (tyttökansalaisia) on muovattu ja kasvatettu 1970-luvun peruskoulussa tasa-arvon ja yhteisöllisen osallistumisen hengessä. Sen sijaan 1990-luvulta alkaen esimerkiksi ammatillisessa koulutuksessa on opittu ajattelutapaan, joka korostaa jokaisen omaa vastuuta osaamisestaan, työllistymisestään sekä menestymisestään. Nykyisin (nais)kansalaisia halutaan myös vastuuttaa yhä enemmän esimerkiksi vanhusten huolenpidosta, mikä tarkoittaa omaehtoista valmiuksien hankkimista omaishoivaan. Tämän päivän kansalaisten sivistys onkin yksilökeskeistä.

Teemanumeron ensimmäinen artikkeli tarkastelee hyvinvointivaltion arvojen ja kansalaistaitojen opettamista, oppimista ja omaksumista 1970-luvun peruskoulussa tyttöjen näkökulmasta. 1970-luvulla toteutetun peruskoulu-uudistuksen perusperiaatteita olivat tasa-arvo ja yhdenvertaisuus. Artikkelissa kysytään, millaisiksi naiskansalaisiksi peruskoulussa kasvatettiin ja kasvettiin. Millaiset roolit olivat tytöille sallittuja ja sopivia? Millaisia arvoristiriitoja kansalaisuuteen kasvattaminen 1970-luvun Suomessa sisälsi? Kouluinstituution kehyksen ja tyttöjen näkökulman kautta pohditaan myös 1970-luvun ajan henkeä sekä yhteiskunnallista tilaa ja muutosta.

Toinen artikkeli tarkastelee sairaanhoitajakoulutusta 1990-2010-luvuilla. Naisvaltaisen ammatin koulutus kertoo osaltaan naiskansalaisuuden ideaaleista ja ehdoista. Artikkeli kuvaa, millaisia uudelleenorientoitumisen vaiheita sairaanhoitajakoulutus ja sen ohjaus sekä alan työmarkkinat ovat kohdanneet hyvinvointivaltion uudelleenmuotoilussa. Artikkelissa analysoidaan, millaista sairaanhoitajuutta ja samalla myös naiskansalaisuutta sairaanhoitajakoulutuksen keskeisissä virallisdokumenteissa tavoitellaan. Lisäksi tarkastellaan, millaisia nais(työ)kansalaisen vaatimuksia terveydenhuollon työyhteisöt välittävät sairaanhoitajaopiskelijoille.

Kolmannessa artikkelissa tullaan 2010-luvulle. Artikkelissa käsitellään (nais)kansalaisten tehtävää hoivaavina yksilöinä. Naiset kantavat suurimman 
vastuun kotona asuvien iäkkäiden omaisten hoivasta, mutta onko heillä siihen tarvittavaa osaamista? Artikkeli pyrkii avaamaan keskustelua siitä, pitäisikö hoivaosaamista tänä päivänä opettaa kansalaisille eikä olettaa hoivaamisen olevan luonnollista.

Hoivasivistystä ei ole sisällytetty vapaan sivistystyön tarjontaan, vaikka tämän päivän yhteiskunnassa sitä tunnutaan kansalaisilta edellytettävän. Hoivasivistys on osa kollektiivista ymmärrystä, joka on luettavissa kansalaisten mielipiteistä siitä, mikä on omaisten ja myös ammattilaisten tehtävä vanhusten hoivassa. Artikkelissa analysoidaan hoivasivistysdiskurssia ja pohditaan, mitä se on. Samalla pohditaan, kenellä on vastuu hoivasivistyksestä ja millainen yhteys sillä on vapaaseen sivistystyöhön.

Teemanumeron artikkeleita yhdistää Sari Sairaanhoitajan kehystarina, joka kuvaa koulutetun naiskansalaisen elämänvaiheita ja -tapahtumia. Sarin tarinassa tulee esiin yhteiskunnassa tapahtuneita merkittäviä muutoksia, joita kasvatus- ja yhteiskuntatietelijöistä koostuva kirjoittajakunta kokoontumisissaan muisteli ja hahmotti. Tarinassa esiintyvät muutokset ovat yhteiskunnallisia tapahtumia ja naisen elämän tärkeitä avainkokemuksia, joita me hyvinvointivaltion naiskansalaisiksi kasvaneina tunnistamme. Sarin tarina on yhdenlainen ajankuva, joka on kollektiivisesti ideoitu ja luotu.

Kehystarinassa kietoutuvat toisiinsa mikro- ja makrotason ilmiöt. Kehystarinassa ei pyritä yhdenmukaiseen, koherenttiin tai totuudenmukaiseen elämäkertakuvaukseen, vaan se on luonteeltaan fragmentaarinen. Se sisältää kirjoittajien muistumia suomalaisessa hyvinvointivaltiossa tapahtuneista merkittävistä käännekohdista ja arkisesta elämästä. Kehystarina ei kuitenkaan ole pelkästään kuvitteellinen tai satunnaiseen muisteluun perustuva, sillä tarinassa on vahvasti mukana tutkimukseen ja kokemukseen perustuvaa tietoa.

\section{KEHYSTARINA: SARI SAIRAANHOITAJA}

Sari syntyy vuonna 1965 esikoisena maaseudulla asuvaan perheeseen. Vuonna 1972 perhe muuttaa keskisuomalaiseen kaupunkiin vanhempien töiden perässä. Perhe asettuu asumaan vastarakennetun lähiön kerrostaloasuntoon, jossa Sarilla on oma huone, kirjoituspöytä ja kasettinauhuri. Kirjoituspöydän kulmalla on Hippo-lipas, johon Sari säästää osan viikkorahoistaan ostaakseen uuden Bay City Rollersin kasetin ja skottiruudullisen kaulahuivin. Sarin perhe asuu kerrostalossa siihen asti, kunnes he pääsevät muuttamaan Sarin isän rakentamaan omakotitaloon.

Sarin isä on syntynyt 1935 ja äiti 1940. Äiti työskenteli ennen maaltamuuttoa meijerissä, joka suljettiin 1970-luvun alussa. Isä työskenteli kirvesmiehenä. 1970-luvun suuressa muutossa kaupungeissa oli tarvetta rakennustyövoimalle. Sarin pikkuveli Vesa syntyy 1967. Kaupunkiin muuton jälkeen Sarin äiti työskentelee ruokakaupan myyjänä ja isä rakennuksilla kirvesmiehenä.

Syksyllä 1972 Sari aloittaa koulunkäynnin peruskoulussa, jossa hän opiskelee äidinkielen lisäksi joukko-oppia, ympäristöoppia, kansalaistaitoa ja nokkahuilun soittoa. Koulun jälkeen Sari menee usein kirjastoon tapaamaan kavereitaan, lainaamaan kirjoja ja kuuntelemaan musiikkia. Sari innostuu musiikista yhä enemmän, kun Abba vuonna 1974 voittaa Euroviisut kappaleellaan Waterloo. Kaupungissa on paljon harrastusmahdollisuuksia ja Sari käy musiikkikerhossa ja balettitunneilla.

Televisio ja sen kahden kanavan ohjelma-anti värittävät Sarin lapsuutta ja muokkaavat hänen maailmankatsomustaan ja arvojaan. Televisio toi kahtiajakautuneen maailman suomalaisiin koteihin: itä ja länsi, kapitalismi ja kommunismi, rikkaat ja köyhät, sorretut ja sortajat, teollisuusmaat ja kehitysmaat. Saria koskettavat erityisesti kuvat Biafran nälkäänäkevistä lapsista ja hän päättää, että isona hän hankkii ammatin, jossa voi auttaa. Saria huolestuttavat myös uutiset lisäydinvoiman rakentamisesta Suomeen.

Sari käy lukion ja kirjoittaa ylioppilaaksi 1984, jonka jälkeen hän päätyy monen ystävänsä ja luokkatoverinsa tavoin opiskelemaan sairaanhoitajaksi, vaikka hän olikin haaveillut lääkärin ammatista. Hän aloittaa vuonna 1987 opistoasteisen sairaanhoitajakoulutuksen. Sukunsa ensimmäisenä ylioppilaana Sarilla ei ole läheisiä, joilla olisi akateeminen tutkinto. Sairaanhoitajan ammatti tuntuu turvalliselta vaihtoehdolta, sillä sairaanhoitajien työllisyys on erittäin hyvä 1980-luvun puolivälissä. 
Opiskeluaikanaan Sari tapaa tulevan miehensä insinööri- ja sairaanhoitajaopiskelijoiden yhteisissä juhlissa. Vuonna 1989 Sari menee naimisiin vastavalmistuneen opistoinsinöörin kanssa ja ottaa kaksiosaisen sukunimen. Perheen ensimmäinen lapsi syntyy vuonna 1991 ja seuraavana vuonna pari saa toisen lapsen. Lasten ollessa pieniä perhe muuttaa miehen työn vuoksi noin sadan kilometrin päähän Sarin vanhemmista.

1990-luvulla Sarin elämää sävyttävät kiireiset vuodet pienten lasten äitinä sekä oman työn kasvavat vaatimukset. Sari toimii sairaanhoitajaopiskelijoiden ohjaajana omalla osastollaan. Ohjaajan rooliin tulee uusia haasteita, kun sairaanhoitajakoulutus 1990-luvulla siirtyy ammattikorkeakouluihin. Myös Sari päättää päivittää oman sairaanhoitajatutkintonsa ammattikorkeakoulutasoiseksi ja hän huomaa viihtyvänsä opiskelijan roolissa.

Myöhemmin Sari kiinnostuu vuonna 2003 aloitetusta muuntokoulutuksesta lääkäriksi. Vaatimuksena koulutukseen on terveydenhuollon tutkinto ja kolmen vuoden työkokemus. Koulutusta on kuitenkin tarjolla vain Turun yliopistossa, mikä tarkoittaisi omalta kotipaikkakunnalta muuttamista. Lääkäriopinnot jäävät edelleen haaveeksi.

Sarin äidillä on nivelrikkoa ja tuki- ja liikuntaelinten vaivoja raskaiden nostamisten ja vetoisten työtilojen johdosta. Isällä oli 1990-luvun laman aikana työttömyysjaksoja ja hän pääsi työeläkeputkeen 1993 ollessaan 58-vuotias. Kun isä vuonna 2003 on 68-vuotias, hänellä alkaa olla muistiongelmia ja sepelvaltimotauti on vaivannut häntä jo jonkin aikaa. Vuonna 2003 äiti on 63-vuotias ja jää myös eläkkeelle. He suunnittelevat viettävänsä paljon aikaa lastenlasten kanssa omakotitalossa, Sarin ja Vesan varhaislapsuuden kodissa. Tultaessa vuoteen 2010 on Sarin äiti 70 ja isä on 75 vuotta vanha.

Vähitellen Sarin isän kunto heikkenee ja Sarin äiti hakee omaishoidon tukea. Sitä ei hänelle myönnetä, koska hänet arvioidaan liian heikkokuntoiseksi kyetäkseen toimimaan omaishoitajana. Äidin hoivavastuu kohdentuu lähinnä 2000-luvulle ja Sarin rooli vanhempien hoivaajana lisääntyy 2010-luvulla. Sarin pikkuveli Vesa keskittyy uraansa ja menee töiden perässä ulkomaan komennuksille. Vesa tarvitsee pal- jon vanhempien ja isosiskon tukea silloin, kun hänen lapsensa ovat pieniä. Myöhemmin, kun vanhemmat tarvitsevat apua ja hoivaa, Vesa irtisanoutuu hoivavastuusta työkiireisiin vedoten, jolloin Sarin tehtävät vanhempien hoidossa lisääntyvät. Sari huolehtii sekä vanhempien hoidosta käytännössä että hakee ja organisoi palveluita ja etuuksia.

\section{Tarja Aaltonen}

YTT, sosiaali- ja terveysalan tuntiopettaja

Tampereen ammattikorkeakoulu

Lea Henriksson

$F T$, sosiaalipolitiikan dosentti Helsingin yliopisto

Anne Laiho

$K T$, yliopistonlehtori, dosentti

Kasvatustieteiden laitos

Turun yliopisto

\section{Eriikka Oinonen}

YTT, sosiologian yliopistonlehtori

Tampereen yliopisto

Tarja Rautiainen-Keskustalo

FT, musiikintutkimuksen professori

Tampereen yliopisto

Tarita Riikonen

$K T$, tutkimuskoordinaattori

Kasvatustieteiden laitos

Turun yliopisto

\section{Tiina Tiilikka}

YTT, sosiaalialan yliopettaja

Seinäjoen ammattikorkeakoulu

Heli Valokivi

YTT, sosiaalityön professori

Lapin yliopisto

Minna Zechner

YTT, sosiaalityön yliopettaja

Seinäjoen ammattikorkeakoulu 


\section{LÄHTEET}

Anttonen, A. (1997). Feminismi ja sosiaalipolitiikka. Tampere: Tampere University Press.

Guaraldo, O. (2001). Storylines. Politics, history and narrative from an arendian perspectives. Jyväskylä: SoPhi, Universtity of Jyväskylä.

Harinen, P. (2000). Valmiiseen tulleet. Tutkimus nuoruudesta, kansalaisuudesta ja kansallisuudesta. Helsinki: Nuorisotutkimusverkosto.

Julkunen, R. (1992). Hyvinvointivaltio käännekohdassa. Tampere: Vastapaino.

Julkunen, R. (2006). Kuka vastaa? Hyvinvointivaltion rajat ja julkinen vastuu. Helsinki: Stakes.

Pyykkönen, M. (2007). Etnisyys, kansalaisuus, integraatio ja hallinta maahanmuuttajien yhdistystoiminnassa. Jyväskylä Studies in Education Psychology and Social Research 306. Jyväskylä: Jyväskylän yliopisto. https://jyx.jyu.fi/dspace/bitstream/ handle/123456789/13323/9789513928728.pdf?seq (14.6.2016)

Tilastokeskus (2016). Naiset ja miehet Suomessa. http:// www.tilastokeskus.fi/uutinen/naiset-ja-miehetsuomessa-2016 (4.8.2016) 